\title{
THE INFLUENCE OF ROAD MAINTENANCE SUBSTANCES ON THE GROWTH OF GRAMINACEOUS PLANTS
}

\author{
Agnė KAZLAUSKIENĖ, Vaida BRUKŠTUTE் \\ Research Institute of Environmental Protection, Vilnius Gediminas Technical University, \\ Sauletekio al. 11, 10223 Vilnius, Lithuania
}

Submitted 15 Apr. 2014; accepted 06 Jan. 2015

\begin{abstract}
The article describes the experimental research on the effect of road maintenance materials on three species of graminaceous plants. The experiment was carried out using technical granular sodium chloride $(\mathrm{NaCl})$ treated with potassium hexacyanoferrate - a road maintenance material most widely applied in wintertime in Lithuania. As an alternative, an organic material obtained on the basis of molasses, patented under the name of Safecote in Europe, was selected for the experiment. Three species of graminaceous plants, most frequently used for roadside planting in Lithuania when building new and reconstructing or renovating the existing motor roads, were analysed: perennial ryegrass (Lolium perenne L.), meadow fescue (Festuca pratensis Huds.), and common meadow-grass (Poa pratensis L.). The paper presents experimental findings regarding the effect of road maintenance materials on the parameters of graminaceous plants - the height of the above-ground part and phytomass.
\end{abstract}

Keywords: graminaceous plant species, perennial rye-grass (Lolium perenne L.), meadow fescue (Festuca pratensis Huds.), common meadow-grass (Poa pratensis L.), molasses, road maintenance salt.

\section{Introduction}

During the cold season, approximately 140000 tons of technical salts are spread on roads to reduce slipperiness in Lithuania. Out of this amount, 70000 to 80000 tons are applied on roads of national significance (data of the Lithuanian Road Administration under the Ministry of Transport and Communications) (Baltrenas, Kazlauskiene 2009a). Technical salts are used to reduce slipperiness in wintertime. They are rather efficient in melting snow and ice but have a negative effect on road components, causing and corrosion of metal parts of motor vehicles as well as $\mathrm{r} / \mathrm{c}$ structures (bridges, tunnels, etc.); they also have a significant impact on the destruction of cement-concrete structures, and deformation of asphalt-concrete paving, etc. (Kamaitis 2002a, 2002b).

These effects are especially evident in cities as streets are surrounded by numerous buildings and structures, leaving no space for roadside ditches that collect snow and salts cleaned off the roadway. In many such cases, it is impossible to immediately collect and transport snow accumulated on sidewalks. The situation is better with roads of national significance due to many open areas and roadside ditches (Baltrènas et al. 2012).
Significant concentrations of road maintenance salts (up to $3200 \mathrm{mg} / \mathrm{l}$ ) accumulate in snow (Baltrènas, Kazlauskienè 2009b) and enter the soil together with meltwater carrying heavy metals (Vainalavičiūte et al. 2009; Mikalajūné, Jakučionytė 2011) and oil products (Žukauskaitè et al. 2008; 2012), which negatively affect roadside vegetation (Dobson 1991; Baltrènas et al. 2006; Darginaviciene et al. 2008) as well as surface and ground waters (Williams et al. 1999) and their fauna (Oškinis, Kaperovičius 2005; Andreikènaite et al. 2007; Vosylienè et al. 2010). As other investigations have shown, soil is alkaline because of cement dust that contains different microelements (Stravinskienè 2011).

By density and quality of its road network, Lithuania equals highly developed states. One of the main aims of road maintenance in winter, aiming to removing snow and ice off road paving and increase the tyre and road paving adhesion coefficient, is to minimise the risk of traffic accidents. Recently, wet salt technology has been applied to protect roads against climatic factors or to de-ice the paving in a very short time. Its effective operation is possible under up to $-15{ }^{\circ} \mathrm{C}$ (Sakshaug, Vaa 1995; Cornford, Thornes 1996; Žilionienè, Laurinavičius 2007). However,

Corresponding author: Agnè Kazlauskienè

E-mail: agne.kazlauskiene@vgtu.lt 
once Lithuania joined the European Union, the requirement has been set to use new generation environmentally friendly materials for road maintenance. With the aim to reduce a negative environmental effect of road maintenance salts, it is expedient to gradually reduce the use of technical salts (in particular in cities) replacing them with alternative new generation substances made on the basis of organic materials (Baltrènas, Kazlauskienè 2009a).

The best practice, improvement of professional skills, scientific research and studies, and dissemination of their results play an important role in the improvement of road infrastructure (Skrinskas 2012).

This research analyses an organic substance molasses - a by-product of sugar manufacturing processes - to minimise road slipperiness and dustiness. In Europe, this product is patented as Safocote. Molasses was presented to the market in Great Britain in 2002. Canada and USA have 14 years of experience using this product, followed by Great Britain, which has been using it for 9 years. In Europe, (Austria, Estonia, Germany, Hungary, Ireland, Norway, Poland, Slovenia, Switzerland and Sweden), it has been in use from 3 to 5 years.

In Vilnius (Lithuania), Safecote was primarily used to decrease street slipperiness during the wintertime of 2005/2006. The amount of 18 tons of Safecote was used during 2006/2007 (Baltrènas, Kazlauskienè 2009a).

Safecote added to a $\mathrm{NaCl}$ solution helps to stay on a road surface 7 times longer and, therefore, no additional treatment is required. It does not cause corrosion of equipment. If technical road maintenance salts were replaced with molasses substance, it would minimise the impact on concrete, bridges, viaducts and asphalt. Furthermore, it would reduce the number of spreader's working hours as well as the number of trips. No additional capital investment in equipment would be required because Safecote can be used with the existing equipment while the required volume of technical salts could be reduced from $30 \%$ to $50 \%$.

Safecote should not be used on roads with low traffic intensity as it can increase a slippery layer, causing threat to traffic safety. Molasses substance is viscous and dark colour. When applied in big quantities, it requires additional washing of streets as well as vehicle maintenance in springtime.

Safecote costs more than technical salts but it is less harmful to the environment. The use of technical salts can be decreased adding $10 \%$ of Safecote to the mixture (Vitaliano 1992; Hanbali 1998; Thornes 2000; Petkuvienè, Paliulis 2009). Such a mixture is an effective solution for ice melting and prevention of slipperiness (Burtwell, Wilson 2002; Burtwell 2004).

Solutions of Safecote in water have been used during summer on the streets and gravel roads to reduce dustiness (Bradulienè, Vasarevičius 2010, 2011, 2012, 2014).
Safecote is a relatively new product; therefore, it is expedient to analyse it and its effect on road environment components. In this research, attention is given to graminaceous plants particular to Lithuania (Braduliené, Vasarevičius 2010, 2011, 2012, 2014).

The impact of Safecote on herbaceous vegetation has been episodically studied in Lithuania and foreign countries (Bradulienè, Vasarevičius 2012).

The aim of the research: to analyse how road maintenance materials affect the growth process and main parameters (the height of the above-ground part and phytomass) of graminaceous plants.

\section{Methods and materials}

Three species of graminaceous plants, most often used for roadside planting in Lithuania when building new or reconstructing and renovating the existing roads, have been selected for this research (Baltrènas et al. 2012). The type of vegetation influences the rate of substrate respiration. Substrates release approximately $20 \%$ of the total $\mathrm{CO}_{2}$ content to the atmosphere (Baltrènas et al. 2011).

The following graminaceous plants have been selected for investigation:

- perennial rye-grass (darimo cultivar) - Lolium perenne L.;

- meadow fescue (prana cultivar) - Festuca pratensis Huds.;

- common meadow-grass (balin cultivar) - Poa pratensis L.

Names of these species have also been mentioned in the article by Jankevičienė (1998).

Also known as molasses, Safecote is an organic material, which is a by-product of sugar refining. This organic material contains minerals, including $\mathrm{Ca}, \mathrm{P}, \mathrm{S}, \mathrm{K}, \mathrm{Na}$, etc. This material is of dark brown colour, liquid and can be mixed with all technical road maintenance salts and their solutions (Baltrènas, Kazlauskienè 2009a; Bradulienè, Vasarevičius 2011, 2012, 2014).

The research was carried out with crushed technical sodium chloride, including potassium hexacyanoferrate $\left(\mathrm{K}_{4}\left[\mathrm{Fe}(\mathrm{CN})_{6}\right]\right)$, hereinafter referred to as $\mathrm{NaCl}$. In Lithuania, the highest quantities of this admixture are used on rods in winter season (Baltrènas, Kazlauskienè 2009b; Baltrènas et al. 2012).

The experiment was carried out as follows: $3 \mathrm{~g}$ of seeds of perennial ryegrass, fescue grass and meadowgrass were each separately planted into 3 plastic containers fully filled with $1 \mathrm{~kg}$ of substrate.

The substrate of the following composition was used for the research: $\mathrm{CaO}-300 \mathrm{mg} / l, \mathrm{NH}_{4}+\mathrm{NO}_{3}-100 \mathrm{mg} / l$, $\mathrm{P}_{2} \mathrm{O}_{5}-50 \mathrm{mg} / \mathrm{l}, \mathrm{MgO}-80 \mathrm{mg} / \mathrm{l}, \mathrm{Fe}_{2} \mathrm{O}_{3}-800 \mathrm{mg} / \mathrm{l}, \mathrm{K}_{2} \mathrm{O}-$ $300 \mathrm{mg} / \mathrm{l}$. 
The research was carried out in two experiments. In experiment I, substrate had been watered with following solutions:

$-5 \mathrm{~g} / \mathrm{kg}$ of Safecote,

$-5 \mathrm{~g} / \mathrm{kg} \mathrm{NaCl}$,

- Mixture of $5 \mathrm{~g} / \mathrm{kg}$ of Safecote and $\mathrm{NaCl}$ salt.

The mixture of Safecote and $\mathrm{NaCl}$ salt was composed of: $4.5 \mathrm{~g} / \mathrm{kg}$ of $\mathrm{NaCl}$ and $0.5 \mathrm{~g} / \mathrm{kg}$ of Safecote. The mixture proportion ( $90 \% \mathrm{NaCl}$ : $10 \%$ Safecote) was selected following Safecote use instructions to reduce slipperiness. Seeking to reduce the required amounts of $\mathrm{NaCl}$, at least $10 \%$ of Safecote of $\mathrm{NaCl}$ amount should be used.

In experiment II, substrate had been watered with following solutions:

$-3 \mathrm{~g} / \mathrm{kg}$ of Safecote,

$-8 \mathrm{~g} / \mathrm{kg}$ of Safecote,

$-10 \mathrm{~g} / \mathrm{kg}$ of Safecote,

- $8 \mathrm{~g} / \mathrm{kg}$ of mixture ( $90 \% \mathrm{NaCl}: 10 \%$ Safecote) composed of $7.2 \mathrm{~g} / \mathrm{kg}$ of $\mathrm{NaCl}$ and $0.8 \mathrm{~g} / \mathrm{kg}$ of Safecote.

Graminaceous plants of the three mentioned species have also been seeded into uncontaminated substrate for control.

During the entire growth period, plats had been growing at the temperature of $+20 \pm 2{ }^{\circ} \mathrm{C}$ and measured humidity of $52( \pm 3) \%$ and daylighting of $160( \pm 10) \mathrm{Lx}$. Certified equipment METREL Poly MI 6401 had been used to measure air temperature and humidity during the experiment.

The experiment lasted for six weeks because this is the exact time, during which, when accessing substrate, road maintenance materials negatively affect the growth process and main parameters of graminaceous plants under both natural and laboratory conditions. During a longer period, road maintenance materials under natural conditions are washed away by precipitation (rain) and their concentrations are diluted. Under laboratory conditions, a similar process takes place when concentration of materials in substrate is reduced during watering of plants. These are the reasons why it is no value in carrying out the experiment for a longer period.

The bottom of each container had holes to allow a natural water run-off and prevent the accumulation of excessive water. Seeds of each species were simultaneously seeded into clean substrate and substrate contaminated with road maintenance materials (control and experimental plants). Both the control and the experimental plants were grown under the same conditions - at the same temperature and lighting. The experimental and control plants were watered once a week with $50 \mathrm{ml}$ of ionised water (Baltrènas, Kazlauskienè 2007; Kazlauskienè 2010).

The height of the above-ground part of graminaceous plants was measured with a calibrated metal ruler Preisser No 11 (with height deviation of $0.026 \mathrm{~mm}$ ). Five samples of each of the graminaceous species were randomly pulled up from containers to measure the average height of the above-ground part $(\mathrm{cm})$. The height of the above-ground part was measured from the start of roots to the end of the longest leaf (Baltrènas, Kazlauskienè 2007; Kazlauskienè 2010).

Phytomass of graminaceous plants was measured with the calibrated electronic analytical balance KERN 770-60 (weighing $0.01 \mathrm{~g} \ldots 60 \mathrm{~g}$, the error is $0.00001 \mathrm{~g}$ ). Five samples of each of the graminaceous species were randomly pulled up from containers to determine the average phytomass (mg). The phytomass was determined with the help of an electronic balance, weighing plants without roots, i.e. only the green above-ground part (Baltrènas, Kazlauskienè 2007; Kazlauskienè 2010).

The height of the above-ground part and the phytomass were measured every week of the experiment, i.e. 6 weeks (Baltrènas et al. 2006; Baltrènas, Kazlauskienè 2009b; Bradulienè, Vasarevičius 2012).

As illustrated in figures, the error of $10 \%$ occurred when measuring the parameters of graminaceous plants.

All data obtained from this experiment is presented as the arithmetic mean of five independent analyses $(x \pm \mathrm{SD}, n=5)$. Significant differences $(p<0.05)$ were deleted from the data evaluation and the measurements were carried out repeatedly. The average characteristics at typical points were:

$$
\bar{c}=\frac{1}{n} \sum_{i=1}^{k} c_{i} m_{i},
$$

where: $c_{i}$ - value of characteristics at typical points; $m_{i}-$ probability at the obtaining of value; $n$ - number of experimental days; $k$ - number of different values of the characteristics (Kazlauskienè et al. 2013).

The above-mentioned average indicators of plants, were also estimated at the typical point. The standard statistical estimation error of the arithmetic average was equal to approx. $10 \%$. The dependencies between different compound characteristics and all indicators in different samples were determined by statistical evaluation using Mathcad 2001 Professional software.

\section{Results}

Experiment I. At the end of the 1st week of the experiment, graminaceous plants showed a very weak germination. Some of the plants did not come up at all or hardly germinated; consequently, the analytical measurements of graminaceous plants were taken on the 2 nd week of the experiment.

After the 2nd week of the experiment, perennial rye-grass had the highest height of its above-ground part compared to plants of other species. Compared to the control, the height of perennial rye-grass in the substrate containing $5 \mathrm{~g} / \mathrm{kg}$ of $\mathrm{NaCl}$ differed by 1.6 times and that of 
meadow fescue - by 3.4 times. After the 3 rd week of the experiment, the height of control plants of perennial ryegrass reached $11.6 \mathrm{~cm}$. The height of the above-ground part of control and perennial rye-grass in the substrate containing $5 \mathrm{~g} / \mathrm{kg}$ of $\mathrm{NaCl}$ differed by 1.8 times. In one week, the difference of perennial rye-grass increased by 0.2 times. On the 4 th week of growth, the height of perennial rye-grass reached $12.7 \mathrm{~cm}$. On the 5 th week of the experiment, perennial rye-grass was $14.0 \mathrm{~cm}$. On the 6th week of growth, the height of the above-ground part of perennial rye-grass in the substrate containing Safecote was weaker compared to that of control plants (Fig. 1).

During the 3rd week of the experiment, the plants grew significantly; however, since then, common meadow-grass no longer germinated in the substrate with $\mathrm{NaCl}$ content. The height of control plants of meadow fescue reached $6.3 \mathrm{~cm}$. Compared to the control, the height of the above-ground part of meadow fescue in the substrate containing $5 \mathrm{~g} / \mathrm{kg} \mathrm{NaCl}$ differed by 2.1 times. In one week, the difference of meadow fescue decreased by 1.3 times. On the 3rd week of growth, the height of plants in the substrate contaminated with Safecote considerably increased. In the substrate contaminated with $\mathrm{NaCl}$ and Safecote, plants were also higher compared to those containing $\mathrm{NaCl}$ alone: perennial rye-grass -1.4 times, meadow fescue -2.3 times. On the 4 th week of growth, the height of meadow fescue reached $7.5 \mathrm{~cm}$. The above-ground part of plants in the substrate contaminated with Safecote was the highest on the 4th and 5th weeks of the experiment. On the 5th week of the experiment, meadow fescue was $8.6 \mathrm{~cm}$ high. Compared to control plants, meadow fescue continued to grow 1.2 times taller.

Analysis of the weekly plant increment shows that the biggest increment of the above-ground part of plants was recorded on the 3 rd week of growth, when perennial rye-grass increased by $1.9 \mathrm{~cm}$ in the substrate contaminated with $5 \mathrm{~g} / \mathrm{kg}$ of $\mathrm{NaCl}$, and $4.1 \mathrm{~cm}$ in the substrate containing the mixture of $\mathrm{NaCl}$ and Safecote. Meadow fescue grew by 1.2 and $2.7 \mathrm{~cm}$, respectively. The increase of graminaceous plants in the substrate contaminated with $\mathrm{NaCl}$ was more even compared to the substrate containing Safecote (Fig. 2).

The height of the above-ground part of plants in the substrate contaminated with $\mathrm{NaCl}$ was the smallest, while common meadow-grass did not germinate at all. On the 3 rd week of the experiment, the height of control plants of common meadow-grass reached $2.8 \mathrm{~cm}$. On the 4 th week of growth, the height of common meadow-grass reached $3.5 \mathrm{~cm}$. On the 5 th week of the experiment, common meadow-grass was $4.8 \mathrm{~cm}$ high. In the substrate containing $\mathrm{NaCl}$, common meadow-grass did not germinate while in the substrate contaminated with the mixture of $5 \mathrm{~g} / \mathrm{kg}$ of Safecote and $\mathrm{NaCl}$ salt grew evenly and increased by $0.4 \mathrm{~cm}$ per week on average (Fig. 3).
During the experiment, phytomass of perennial ryegrass was changing depending on contamination of the substrate. After two weeks of growth, phytomass of perennial rye-grass control plants was $8.9 \mathrm{mg}$; that of plants in the substrate containing $5 \mathrm{~g} / \mathrm{kg}$ of $\mathrm{NaCl}-7.5 \mathrm{mg}$; in the substrate containing $5 \mathrm{~g} / \mathrm{kg}$ of Safecote $-8.6 \mathrm{mg}$; and in the substrate contaminated with the mixture of $5 \mathrm{~g} / \mathrm{kg}$ $\mathrm{NaCl} /$ Safecote $-7.1 \mathrm{mg}$. Other weeks of the experiment showed a clear dependence of phytomass on the specificity on substrate contamination. The weakest phytomass of perennial rye-grass was in the substrate containing $5 \mathrm{~g} / \mathrm{kg} \mathrm{NaCl}$. The phytomass of plants in the substrate

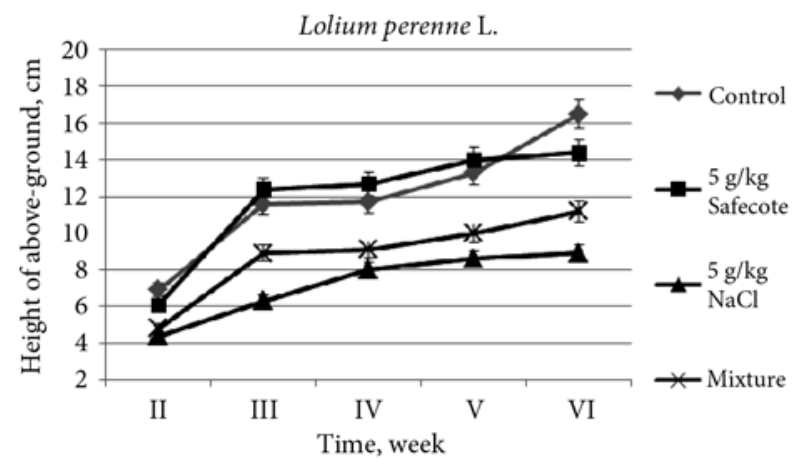

Fig. 1. Change in the height of the above-ground part of perennial rye-grass (Lolium perenne L.) (Experiment I)

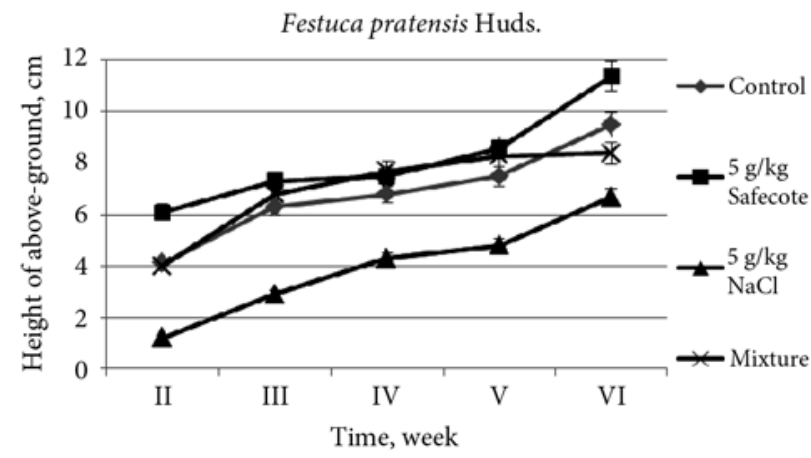

Fig. 2. Change in the height of the above-ground part of meadow fescue (Festuca pratensis Huds.) (Experiment I)

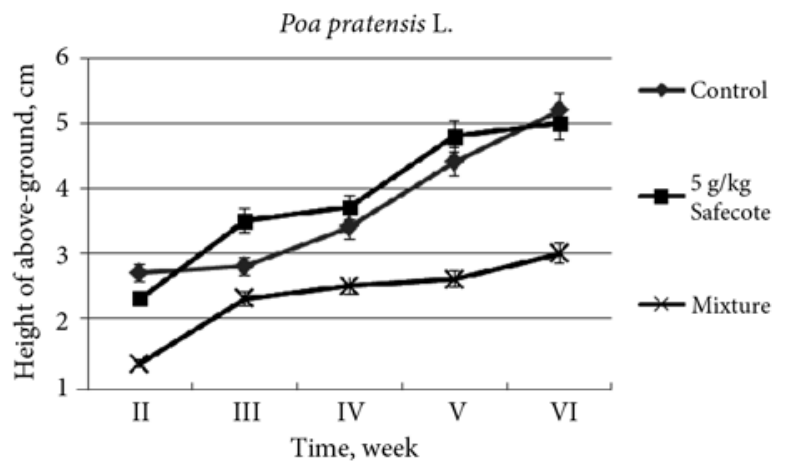

Fig. 3. Change in the height of the above-ground part of common meadow-grass (Poa pratensis L.) (Experiment I) 


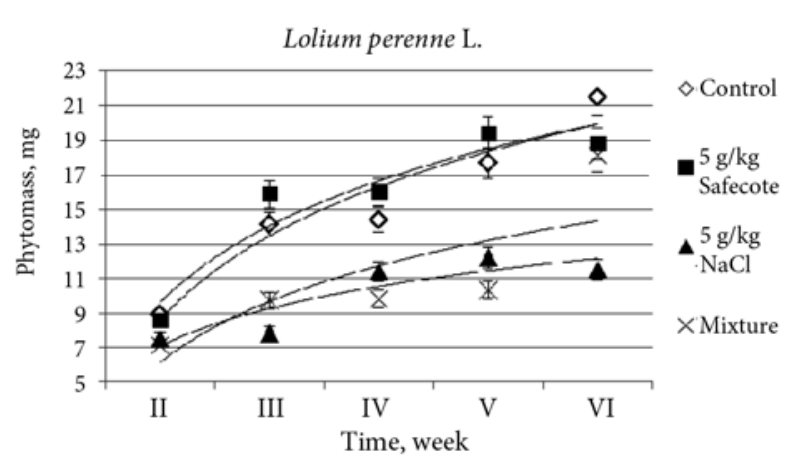

Fig. 4. Change in phytomass of perennial rye-grass (Lolium perenne L.) (Experiment I)

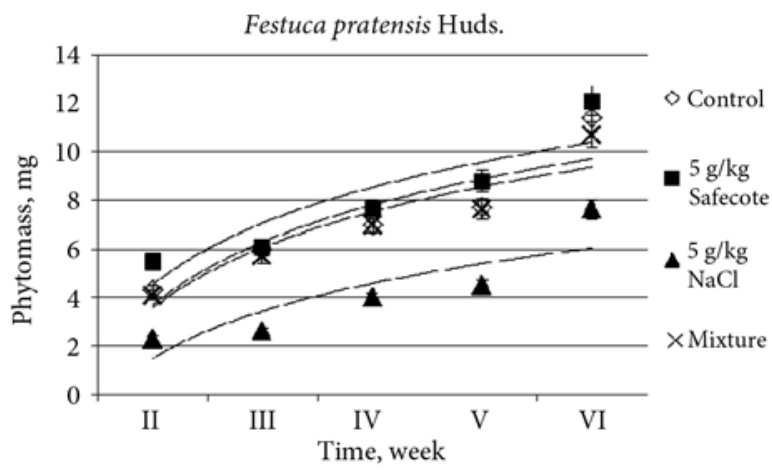

Fig. 5. Change of in phytomass of meadow fescue (Festuca pratensis Huds.) (Experiment I)

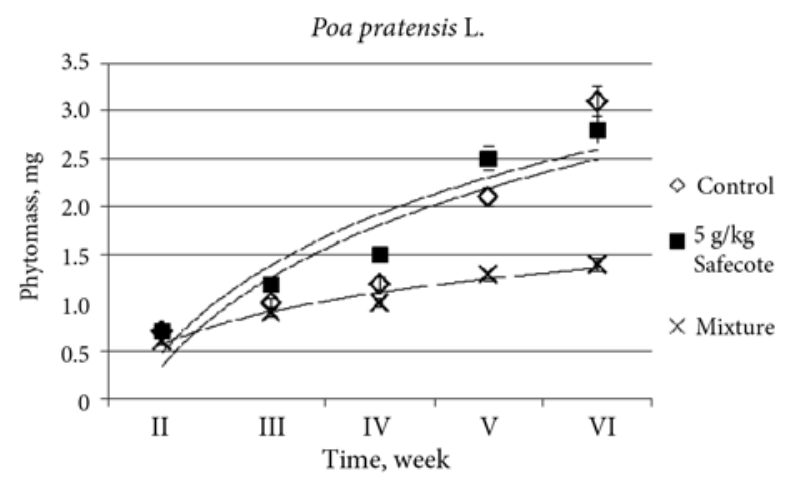

Fig. 6. Change in phytomass of common meadow-grass (Poa pratensis L.) (Experiment I)

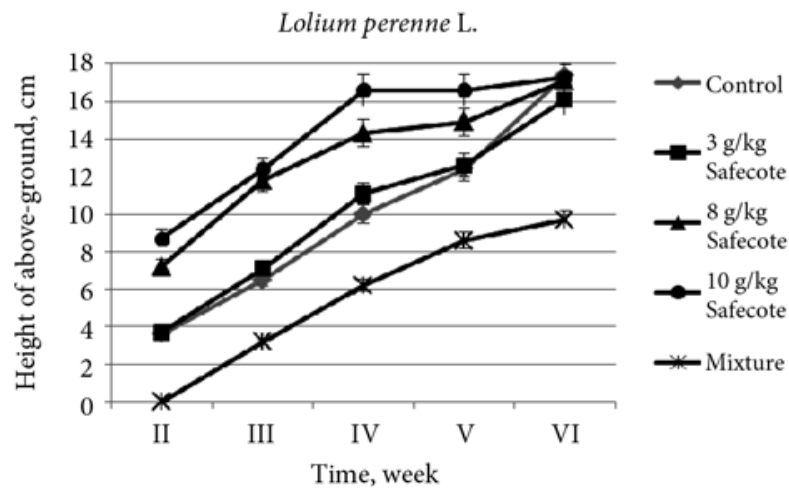

Fig. 7. Change in phytomass of perennial rye-grass (Lolium perenne L.) (Experiment II) contaminated with the mixture of $5 \mathrm{~g} / \mathrm{kg} \mathrm{NaCl}$ and Safecote, was bigger compared to the substrate containing only $\mathrm{NaCl}$ but by $4 \mathrm{mg}$ smaller than that of control plants. Tor five weeks, in the substrate contaminated only with $5 \mathrm{~g} / \mathrm{kg}$ Safecote, phytomass of perennial rye-grass was on average $1.7 \mathrm{mg}$ bigger than that of control plants but after week 6 it decreased by $2.7 \mathrm{mg}$ (Fig. 4).

Phytomass values of meadow fescue in substrates contaminated only with Safecote and the mixture of Safecote and $\mathrm{NaCl}$ were similar. As Figure 5 shows, phytomass of plants in the substrate contaminated with the mixture of $5 \mathrm{~g} / \mathrm{kg} \mathrm{NaCl}$ and Safecote was somewhat smaller than that of control plants, while in the substrate contaminated only with Safecote, it was inconsiderably bigger compared to control plants. A significant difference in phytomass of perennial rye-grass in the substrate containing $5 \mathrm{~g} / \mathrm{kg}$ $\mathrm{NaCl}$ and the control substrate, i.e. $3.8 \mathrm{mg}$, was recorded after growth weeks 3 and 6 .

During the first four weeks of the experiment, phytomass of common meadow-grass in differently contaminated substrates was changing evenly. From week 4 to week 6 , a significant difference in phytomass change was recorded: in the substrate contaminated with the mixture of $5 \mathrm{~g} / \mathrm{kg}$ of $\mathrm{NaCl}$ and Safecote, plants grew by only $0.4 \mathrm{mg}$, while in the control substrate $-2.1 \mathrm{mg}$, and in the substrate containing $5 \mathrm{~g} / \mathrm{kg}$ of Safecote - $1.3 \mathrm{mg}$. Just as in the case of perennial rye-grass, phytomass of common meadow-grass in the substrate contaminated only with Safecote was bigger than that of control plants (Fig. 6). During the experiment, common meadow-grass has not germinated in the substrate containing $5 \mathrm{~g} / \mathrm{kg}$ of $\mathrm{NaCl}$. Within the growth period, phytomass of common meadow-grass grass was the smallest compared to perennial rye-grass and meadow fescue.

Experiment I showed that when added into the substrate, Safecote had a positive effect on the growth process of graminaceous vegetation.

Experiment II. As mentioned in the methodology, only two Safecote concentrations $-5 \mathrm{~g} / \mathrm{kg}$ and $0.5 \mathrm{~g}$ in the mixture with $\mathrm{NaCl}$ - were added to the substrate in the first part of the experiment. To confirm experimental findings, it was decided to continue the experiment by analysing at least several more concentrations of Safecote ( $3 \mathrm{~g} / \mathrm{kg}$, $8 \mathrm{~g} / \mathrm{kg}, 10 \mathrm{~g} / \mathrm{kg}$ ) and one more high concentration mixture with $\mathrm{NaCl}(7.2 \mathrm{~g} / \mathrm{kg} \mathrm{NaCl}$ and $0.8 \mathrm{~g} / \mathrm{kg}$ Safecote).

After the 2nd week, perennial rye-grass had the longest above-ground part compared to plants of the other 2 species, i.e. common meadow-grass and meadow fescue.

After the 2nd week of growth, it has become clear that the higher is Safecote concentration, the bigger is the height of the above-ground part of plants. After week 2, all plants growing in the substrate contaminated only with Safecote were taller than the control plants. After week 2, none of the plant species germinated in the substrate 
contaminated with the mixture of $8 \mathrm{~g} / \mathrm{kg} \mathrm{NaCl}$ and Safecote. Compared to the control substrate, the height of the above-ground part of perennial rye-grass in the substrate containing $10 \mathrm{~g} / \mathrm{kg}$ of Safecote, differed by 1.9 times (Fig. 7 ).

The plants significantly grew on the experiment's $3^{\text {rd }}$ week. The height of control plants of perennial ryegrass reached $6.5 \mathrm{~cm}$, that of fescue-grass $-3.4 \mathrm{~cm}$, common meadow-grass $-2.3 \mathrm{~cm}$. The above-ground part height of meadow fescue differed by 2.4 times in substrate containing $10 \mathrm{~g} / \mathrm{kg}$ of Safecote, when compared to control substrate. Perennial rye-grass reached the height of $3.2 \mathrm{~cm}$ In substrate contaminated with the mixture of $8 \mathrm{~g} / \mathrm{kg} \mathrm{NaCl}$ and Safecote, fescue-grass $-1.5 \mathrm{~cm}$ while common meadow-grass did not germinate even after the $3^{\text {rd }}$ week (Figs 7,8$)$.

Compared to the control substrate on the 3 rd week of growth, the height of the above-ground part of common meadow-grass in the substrate containing $10 \mathrm{~g} / \mathrm{kg}$ of Safecote differed by 2.2 times. On weeks 4 and 5 of the experiment, the height of plants was the greatest in the substrate containing $10 \mathrm{~g} / \mathrm{kg}$ of Safecote: on the 4 th week, the height of perennial rye-grass reached $16.6 \mathrm{~cm}$, that of meadow fescue $-10.8 \mathrm{~cm}$, common meadowgrass $-7.2 \mathrm{~cm}$; on the 5 th week perennial rye-grass was 16.6, fescue-grass $12.7 \mathrm{~cm}$ and common meadow-grass $12.0 \mathrm{~cm}$ tall (Figs 7, 8, 9).

On the 6th week of growth, perennial rye-grass in differently contaminated substrates showed nearly the same height of its above-ground part, former differences disappeared. The highest perennial rye-grass plants were in control pots and reached $17.4 \mathrm{~cm}$. However, the difference in heights of fescue-grass and common meadowgrass plants in differently contaminated substrates continued to remain significant. The height of fescue-grass and common meadow-grass in all substrates contaminated with Safecote was greater than that of control plants that were watered only with ionised water (Figs 7, 8, 9).

In the substrate contaminated with the mixture of $8 \mathrm{~g} / \mathrm{kg} \mathrm{NaCl}$ and Safecote, perennial rye-grass and meadow fescue germinated only on the 3 week of the experiment, while common meadow-grass has not germinated during the entire experiment. Every week germinated plants showed an average increase of: perennial ryegrass $-2.4 \mathrm{~cm}$, meadow fescue $-1.4 \mathrm{~cm}$. After 6 weeks of growth, the height of the above-ground part of perennial rye-grass reached $9.7 \mathrm{~cm}$ and that of fescue-grass $5.5 \mathrm{~cm}$. During the experiment, the height of the aboveground part of plants in the substrate contaminated with the mixture of $\mathrm{NaCl}$ and Safecote was smaller than that of control plants (Figs 7, 8, 9).

Phytomass of perennial rye-grass was changing diversely depending on contamination of the substrate. Phytomass of control plants was evenly increasing by the average of $4 \mathrm{mg}$ per week. Phytomass of plants in the substrate with $3 \mathrm{~g} / \mathrm{kg}$ Safecote content and the substrate containing the mixture of $8 \mathrm{~g} / \mathrm{kg} \mathrm{NaCl}$ and Safecote was changing similarly to that of control plants but plants in the substrate contaminated with the mixture of $\mathrm{NaCl}$ and Safecote had the weakest phytomass. Compared to control plants, it was $0.1 \mathrm{mg}$ less on the 2 nd growth week, $3 \mathrm{mg}$ - 3rd week, $0.7 \mathrm{mg}$ - 4 th week, $1.9 \mathrm{mg}$ - 5th week, and $1.5 \mathrm{mg}-6$ th week. Plants in substrates containing $8 \mathrm{~g} / \mathrm{kg}$ Safecote and $10 \mathrm{~g} / \mathrm{kg}$ Safecote had bigger phytomass compared to control plants (Fig. 10).

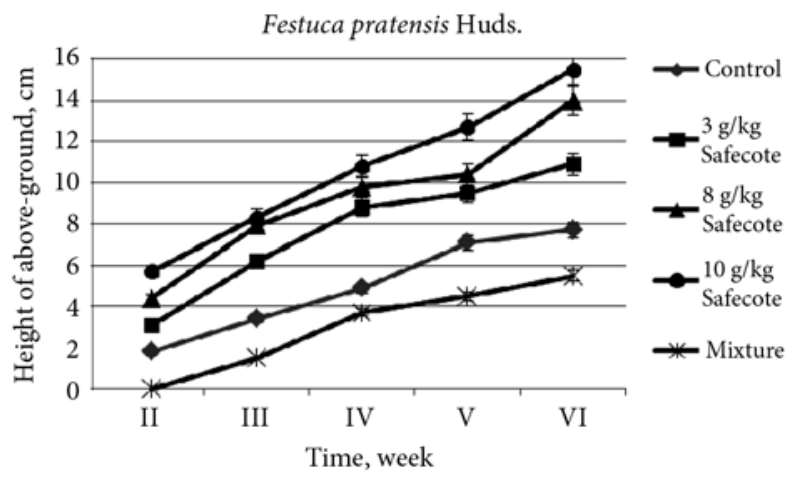

Fig. 8. Change of meadow fescue (Festuca pratensis Huds.) height of above-ground (Experiment II)

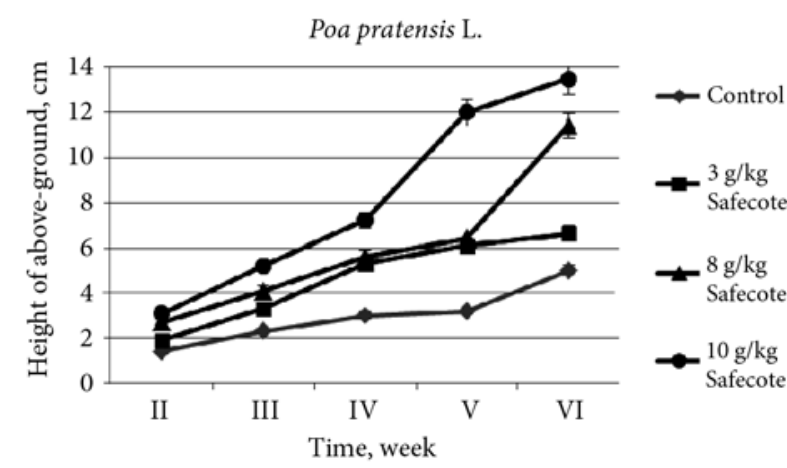

Fig. 9. Change the above-ground height of common meadowgrass (Poa pratensis L.) (Experiment II)

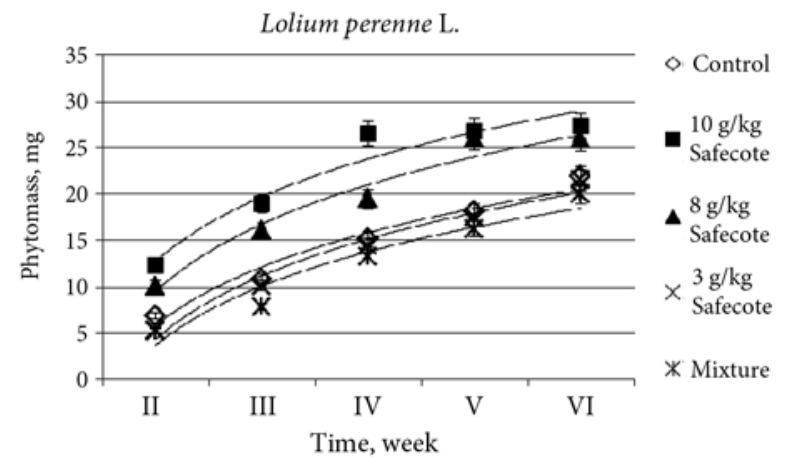

Fig. 10. Change in phytomass of perennial rye-grass (Lolium perenne L.) (Experiment II) 
As illustrated in Figure 11, the biggest variation in the height of above-ground part of perennial ryegrass was in week when temperature was changed approximately $2{ }^{\circ} \mathrm{C}$. Correlation coefficient of variation of above-ground part of perennial ryegrass and temperature was equal to 0.62 .

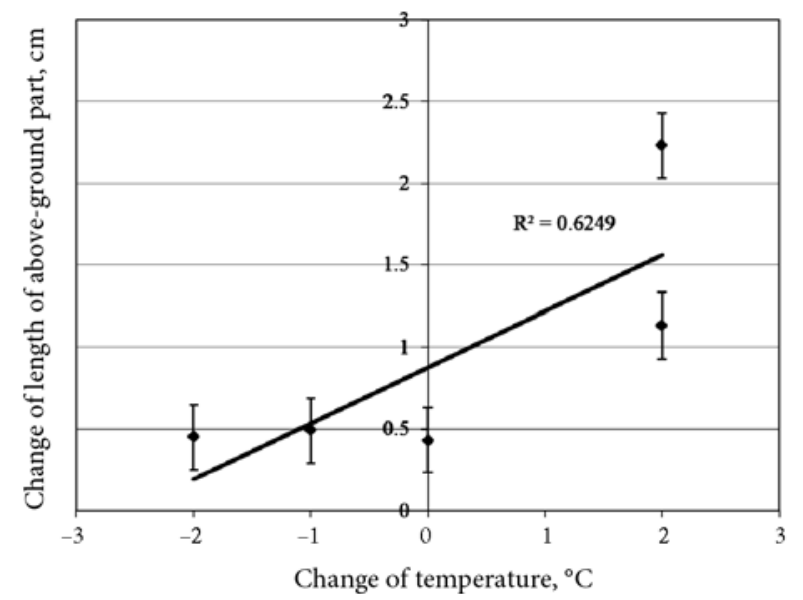

Fig. 11. Variation of the height of the above-ground part of perennial rye-grass (Lolium perenne L.) in relation to temperature (Experiment II)

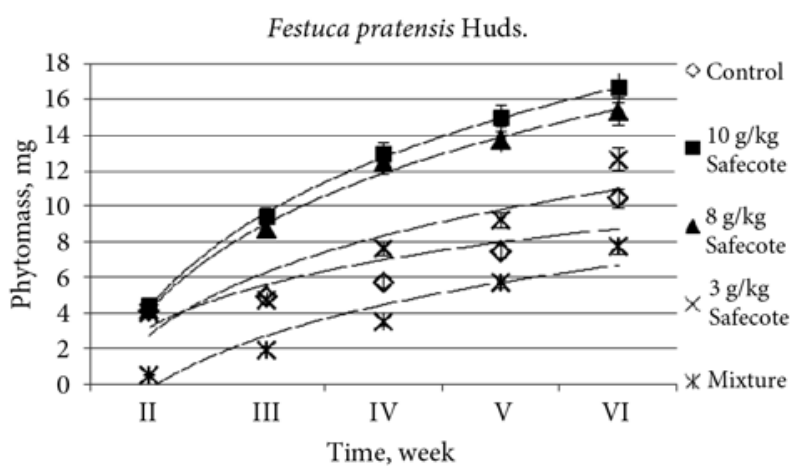

Fig. 12. Change in phytomass of meadow fescue (Festuca pratensis Huds.) (Experiment II)

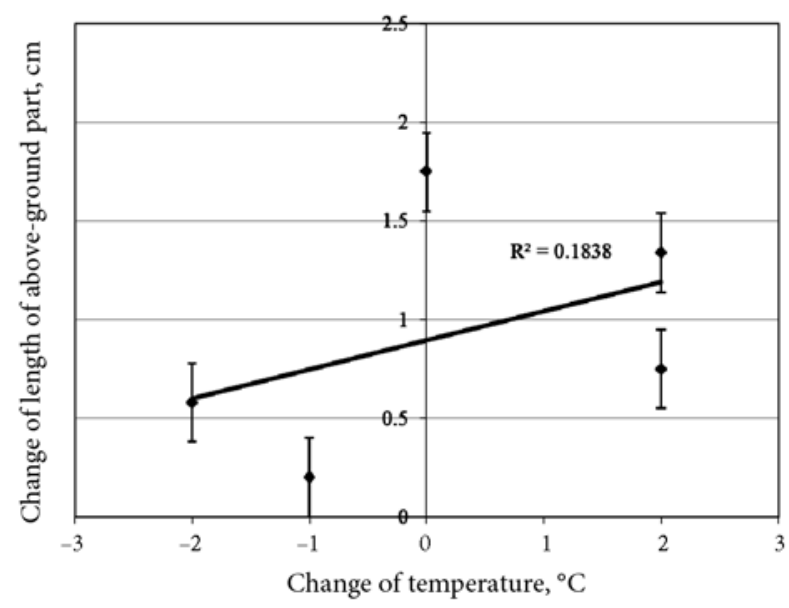

Fig. 13. Variation of the height of the above-ground part of meadow fescue (Festuca pratensis Huds.) in relation to temperature (Experiment II)
Obvious differences in phytomass of meadow fescue have been recorded in the substrate with Safecote content. The higher was Safecote concentration in the substrate, the bigger was phytomass of plants. Phytomass of plants in the substrate contaminated with the mixture of $8 \mathrm{~g} / \mathrm{kg} \mathrm{NaCl}$ and Safecote, was weaker than that of control plants: after 2 weeks - $3.5 \mathrm{mg}$, after 3 weeks $2.9 \mathrm{mg}$, after 4 weeks $-2.2 \mathrm{mg}$, after 5 weeks - $1.7 \mathrm{mg}$, after 6 weeks - $2.7 \mathrm{mg}$ (Fig. 12).

As illustrated in Figure 13, the biggest variation in the height of the above-ground part of fescue grass was recorded on the week when the temperature was changed to $0{ }^{\circ} \mathrm{C}$. The correlation coefficient of variation of the above-ground part of fescue grass and temperature was equal to 0.18 .

During the first weeks of the experiment, phytomass of common meadow-grass was changing gradually and after the 4th week, it amounted to the average of $2.0 \mathrm{mg}$. Common meadow-grass in the substrate with $10 \mathrm{~g} / \mathrm{kg}$ Safecote content was distinguished by somewhat bigger phytomass. From week 4 to week 6, a big difference in the change of phytomass was recorded: in substrates with $8 \mathrm{~g} / \mathrm{kg}$ and $10 \mathrm{~g} / \mathrm{kg}$ of Safecote content, plants increased by $7.1 \mathrm{mg}$ and $8.2 \mathrm{mg}$, respectively. Phytomass of common meadow-grass, just as that of perennial rye-grass, was bigger in pots with higher concentration of Safecote (Fig. 14).

As illustrated in Figure 15, the biggest change in the height of the above-ground part of meadow-grass was recorded on the week when the temperature was changed to $0{ }^{\circ} \mathrm{C}$. The correlation coefficient of variation of the above-ground part of meadow-grass and temperature was 0.01 .

\section{Discussion}

J. Bradulienè and S. Vasarevičius (2012) investigated the impact of different concentrations of Safecote and Safecote mixture with $\mathrm{CaCl}_{2}$ on timothy-grass

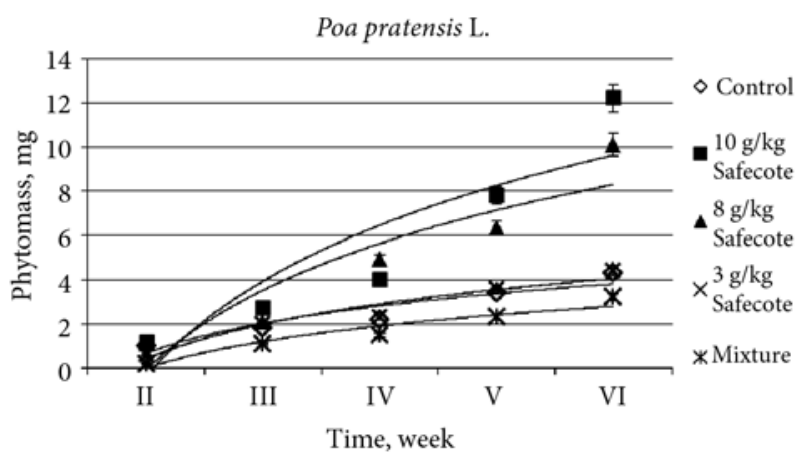

Fig. 14. Change in phytomass of common meadow-grass (Poa pratensis L.) (Experiment II) 


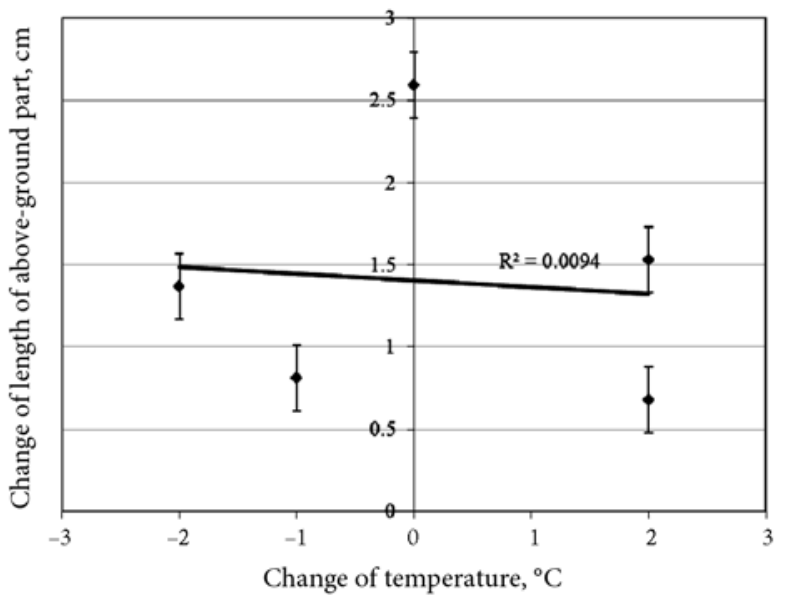

Fig. 15. Variation of the height of the above-ground part of common meadow-grass (Poa pratensis L.) in relation to temperature (Experiment II)

(Phleum pratense L.), white clover (Trifolium repens L.) and crimson clover (Trifolium incarnatum L.). These researchers found that the height of herbaceous plants above the ground has a linear dependency on Safecote concentrations in the soil, i.e. the greater is the concentration of Safecote, the higher part of herbaceous plants was above the ground.

The comparison of results with those of earlier investigations regarding the toxic impact of $\mathrm{NaCl}$ on herbaceous vegetation (Baltrènas et al. 2006; Baltrènas, Kazlauskienè 2007, 2009b; Baltrènas et al. 2012) established that a negative influence of $\mathrm{NaCl}$ on vegetation parameters can be reduced by changing some part of $\mathrm{NaCl}$ to Safecote, e.g. making mixtures. The research results show that technical salts have an adverse effect on the growth of grass plants by slowing down the growth of the above-ground part of plants and limiting their phytomass.

\section{Conclusions}

1. Findings of the experiment show that perennial rye-grass had the biggest and meadow grass - the smallest phytomass among the analysed graminaceous plants grown in contaminated substrate.

2. During the experiment, it was determined that perennial rye-grass reached the highest, while meadow grass - the lowest height of the above-ground part of plants.

3. Findings of the experiment also showed that perennial rye-grass had the highest resistance to the toxic effect of salts while common meadow-grass - the lowest as it did not germinate in substrates with big concentrations (5-8 g/kg) of $\mathrm{NaCl}$.

4. Safecote infiltrated into the soil had a positive impact on the growth of herbaceous vegetation, e.g. it accelerated the growth of the part of plants above the ground and increased their biomass. The higher was Safecote concentration in the soil (in this research, the highest was $10 \mathrm{~g} / \mathrm{kg}$ ), the better it improved the height of herbaceous plants above the ground and added to their phytomass.

5 . It has been experimentally proved that the content of $\mathrm{NaCl}$ in the substrate has a negative effect on the growth process of graminaceous vegetation, i.e. it retards the increment of the above-ground part and reduces phytomass.

6. Herbaceous vegetation grown in the soil with Safecote, sometimes showed higher parameters compared to control plants (even till 50\%); consequently, mineral compounds of Safecote ingredients can be used as soil fertilisers to improve condition of plants. When inserted into the substrate, Safecote had a positive effect on the growth process of graminaceous vegetation, i.e. accelerated the increment of the above-ground part of plants and increases their phytomass. The higher was Safecote concentration in the substrate, the greater was the height of the aboveground part and phytomass of graminaceous vegetation. In some cases, graminaceous plants in the substrate with Safecote content showed better parameters than those in the control substrate.

7. When $\mathrm{NaCl}$ application was reduced by $10 \%$, replacing it with the same amount of Safecote, the substrate condition was improved with mineral substances and favourable conditions for plant development were created.

\section{References}

Andreikènaite, L.; Bakšienė, J.; Vosylienè, M. Z. 2007. Studies of micronuclei and other nuclear abnormalities in blood of rainbow trout (Oncorhynchus mykiss) treated with heavy metal mixture and road maintenance salts, Acta Zoologica Lituanica 17(3): 213-219.

http://dx.doi.org/10.1080/13921657.2007.10512834

Baltrènas, P.; Kazlauskienè, A. 2007. Grass vegetation dynamics in soil contaminated with salt, Ekologija 53(3): 58-63.

Baltrènas, P.; Kazlauskiene, A. 2009a. Sustainable ecological development reducing negative effects of road maintenance salts, Technological and Economic Development of Economy 15(1): 178-188. http://dx.doi.org/10.3846/1392-8619.2009.15.178-188

Baltrènas, P.; Kazlauskienè, A. 2009b. Selection of grass vegetation species resistant to road maintenance salts, in J. P. Navarro-Aviñó (Ed.). Phytoremediation: the green salvation of the world. Research Signpost, 1-24.

Baltrènas, P.; Kazlauskienè, A.; Mikalajūnè, A. 2012. Aplinkos apsauga keliuose: monografija [Roads Environment Protection. Monograph]. Vilnius: Technika. 384 p.

Baltrènas, P.; Kazlauskienè, A.; Zaveckytè, J. 2006. Experimental investigation into toxic impact of road maintenance salt on grass vegetation, Journal of Environmental Engineering and Landscape Management 14(2): 83-88.

Baltrènas, P.; Pranskevičius, M.; Lietuvninkas, A. 2011. Investigation and evaluation of carbon dioxide emissions from soil in Neris Regional Park, Journal of Environmental Engineering and Landscape Management 19(2): 115-122. http://dx.doi.org/10.3846/16486897.2011.580917 
Bradulienè, J.; Vasarevičius, S. 2010. Žvyrkelių dulkètumo mažinimo tirpalu „Safecote“ ir jo mišiniu su $\mathrm{CaCl}_{2}$ eksperimentiniai tyrimai [Experimental investigation into reduction of gravel road dustiness using "Safecote" solution and its mixture with $\mathrm{CaCl}_{2}$ ], Journal of Environmental Engineering and Landscape Management 18(2): 145-153. http://dx.doi.org/10.3846/jeelm.2010.17

Bradulienè, J.; Vasarevičius, S. 2011. Žvyrkelio dulkejjimo ir aplinkos sąlygų sąryšio statistinis įvertinimas, dulkèjimui mažinti naudojant tirpalą melasos pagrindu [Statistical evaluation of the relationship between gravel road dustiness and environmental conditions using molasses solution for reducing dustiness], Mokslas - Lietuvos ateitis - Science -Future of Lithuania 3(5): 5-11.

http://dx.doi.org/10.3846/mla.2011.079

Bradulienè, J.; Vasarevičius, V. 2012. The impact on grass vegetation of materials reducing gravel road dustiness, The Baltic Journal of Road and Bridge Engineering 7(4): 288-296. http://dx.doi.org/10.3846/bjrbe.2012.38

Bradulienè, J.; Vasarevičius, V. 2014. Investigations of gravel road dust minimization by applying different salt solutions, Polish Journal of Environmental Studies 23(3): 943-948.

Burtwell, M. 2004. Assessment of Safecote: new deicer product, in Proceeding of $6^{\text {th }}$ International Symposium on Snow Removal and Ice Control Technology, 7-9 June 2004, Spokane, Washington, 529-540.

Burtwell, M.; Wilson, M. 2002. Safecote de-icer in UK winter maintenance, Highways 71(10): 5-13.

Cornford, D.; Thornes, J. E. 1996. A comparison between, spatial winter indices and expenditure on winter road maintenance in Scotland, International Journal of Climatology 16: 339-357. http://dx.doi.org/10.1002/(SICI)10970088(199603)16:3<339::AID-JOC40>3.0.CO;2-U

Darginaviciene, J.; Pasakinskiene, I.; Maksimov, G.; Rognli, O. A.; Jurkoniene, S.; Sveikauskas, V.; Bareikiene, N. 2008. Changes in plasmalemma $\mathrm{K}^{+} \mathrm{Mg}^{2+}$-ATPase dephosphorylating activity and $\mathrm{H}^{+}$transport in relation to freezing tolerance and seasonal growth of Festuca pratensis Huds, Journal of Plant Physiology 165: 825-832. http://dx.doi.org/10.1016/j.jplph.2007.07.009

Dobson, M. C. 1991. De-icing salt damage to trees and shrubs. Forestry commission, Bulletin 101, HMSO, London. 64 p.

Hanbali, R. M. 1998. The economic impact of winter road maintenance on road users, Transportation Research Record 1442: 429-439.

Jankevičienè, R. 1998. Botanikos vardų žodynas. Vilnius: Botanikos instituto leidykla. $524 \mathrm{p}$.

Kamaitis, Z. 2002a. Damage to concrete bridges due to reinforcement corrosion. Part I. Site investigations, Transport 17(4): 137-142.

Kamaitis, Z. 2002b. Damage to concrete bridges due to reinforcement corrosion: part II-design considerations, Transport 17(5): 163-170.

Kazlauskienè, A. 2010. Žolinių augalų augimo dinamika natrio formiatu užterštame dirvožemyje [The dynamics of growing herbaceous plants in the soil contaminated with sodium formate], Mokslas - Lietuvos ateitis - Science - Future of Lithuania 2(5): 36-40. http://dx.doi.org/10.3846/mla.2010.088

Kazlauskienė, A.; Valentukevičienè, M.; Ignatavičius, G. 2013. Sustainability assessment of heavy metals and road maintenance salts in sweep sand from roadside environment,
Technological and Economic Development of Economy 19(2): 224-236. http://dx.doi.org/10.3846/20294913.2013.796500

Mikalajūnè, A.; Jakučionyte, L. 2011. Investigation into heavy metal concentration by the gravel roadsides, Journal of Environmental Engineering and Landscape Management 19(1): 89-100. http://dx.doi.org/10.3846/16486897.2011.557474

Oškinis, V.; Kasperovičius, T. 2005. Impact of road maintenance salts on water ecosystems according to diatom flora investigation, Journal of Environmental Engineering and Landscape Management 13(1): 51-55.

Petkuvienè, J.; Paliulis, D. 2009. Experimental research of road maintenance salts and molasses ("Safecote") corrosive impact on metals, Journal of Environmental Engineering and Landscape Management 17(4): 236-243. http://dx.doi.org/10.3846/1648-6897.2009.17.236-243

Sakshaug, K.; Vaa, T. 1995. Road salting and traffic safety - the effect of road salting on accidents and driving speed. Report No. STF63 A95005, SINTEF transport engineering, Norway. $59 \mathrm{p}$.

Skrinskas, S. 2012. International and scientific activities of the Lithuanian road administration are the source of experience, The Baltic Journal of Road and Bridge Engineering 7(3): 169-172. http://dx.doi.org/10.3846/bjrbe.2012.23

Stravinskienè, V. 2011. Pollution of "Akmenès cementas" vicinity: alkalizing microelements in soil, composition of vegetation species and projection coverage, Journal of Environmental Engineering and Landscape Management 19(2): 130-139. http://dx.doi.org/10.3846/16486897.2011.579449

Thornes, J. E. 2000. Road salting - an international benefit/cost review, in Proceeding of the $8^{\text {th }}$ World Salt Symposium, 7-11 May 2000, Hague, the Netherlands 2: 787-791. Elsevier.

Vainalavičiūtè, R.; Kazlauskienè, A.; Baltrènas, P.; Jankaitè, A. 2009. Investigation of particulate matter and chloride concentrations in the environment of gravelled roads, Geologija 51(1-2): 1-11. http://dx.doi.org/10.2478/v10056-009-0001-5

Vitaliano, D. F. 1992. An economic assessment of the social costs of highway salting and the efficiency of substituting a new de-icing material, Journal of Policy Analysis and Management 2(3): 397-418. http://dx.doi.org/10.2307/3325069

Vosylienė, M. Z.; Kazlauskienè, A.; Mikalajūnè, A. 2010. Alterations in selected haematological parameters of rainbow trout (Oncorhynchus mykiss) exposed to complex mixtures of contaminants, Environment Protection Engineering 36(4): 95-104.

Williams, D. D.; Williams, N. E.; Cao, Y. 1999. Road salt contamination of groundwater in a major metropolitan area and development of a biological index to monitor its impact, $\mathrm{Wa}$ ter Research 34(1): 127-138. http://dx.doi.org/10.1016/S0043-1354(99)00129-3

Žilioniene, D.; Laurinavičius, A. 2007. De-icing experience in Lithuania, The Baltic Journal of Road and Bridge Engineering 2(2): 73-79.

Žukauskaitè, A.; Jakubauskaite, V.; Belous, O.; Ambrazaitienė, D.; Stasiškiene, Ž. 2008. Impact of heavy metals on the oil products biodegradation process, Waste Management \& Research 26: 500-507. http://dx.doi.org/10.1177/0734242X08089838

Žukauskaitè, A.; Jakubauskaitè, V.; Ambrazaitienė, D.; Zabukas, V.; Paulauskiene, T. 2012. The impact of chemical additives on the process of biodegradation of oil products, Journal of Environmental Engineering and Landscape Management 20(1): 17-26. http://dx.doi.org/10.3846/16486897.2011.633336 
Agnè KAZLAUSKIENĖ is a researcher of the Research Institute of Environmental Protection, Doctor of Technological Sciences (Environmental Engineering), Dep. of Environmental Protection, Vilnius Gediminas Technical University (VGTU). Author of 14 scientific publications and 1 invention. Research interests: environmental pollution, road maintenance substances, environmental monitoring.

Vaida BRUKŠTUTE். Master of Science (Environmental Engineering), Dep. of Environmental Protection, Vilnius Gediminas Technical University (VGTU). Bachelor of Science (Environmental Engineering), VGTU, 2007. Research interests: environmental protection, pollution prevention. 